\section{Extended uses of scalp vein set in plastic surgery}

Sir,

Winged infusion set - also known as "Butterfly or scalp vein set" is a device primarily used for venipuncture.

It consists of a hypodermic needle, two bilateral flexible wings, flexible small bore transparent tubing $(20-35 \mathrm{~cm}$ long), a connector (female Leur). Sizes 8-24G (22 and 23G are most common).

Scalp vein set can be used for multiple procedures in plastic surgery:

1. Saline infusion and removal from tissue expander.

2. Penrose type tube drain in wound margins.

3. Continuous suction drain.

4. Irrigation of wound.

5. Tourniquet for finger, penis.

6. Dye injection in sinus/fistula to delineate cavity/tract.

7. Soft cover over cut K-wire used after fracture fixation of digits.

8. For venipuncture.

The most common use of scalp vein set in plastic surgery is an infusion of saline in tissue expander [Figure 1]. It can be connected to a syringe to infuse saline without repetitive punctures to skin and port. Furthermore, it can be used to evacuate the fluid from the expander after removal from the body.

The scalp vein set can be used as a continuous suction drain [Figure 2]. It needs to be connected to a $10 \mathrm{ml}$ syringe and 2 cc syringe piston to maintain negative suction. Apart from it, small pieces of scalp vein can be used as Penrose type tube drains [Figure 3] for suture site.

Scalp vein set can be used for continuous irrigation of any wound when connected to saline infusion. ${ }^{[1]}$ After an adequate number of irrigation holes have been made a scalp vein infusion set is placed into the wound ${ }^{[2]}$ Scalp vein set is soft hence it can be used as a tourniquet for finger and penis [Figure 4]. It is fixed in position at appropriate tension with the help of a haemostat.

It can be used for instillation of dye (methylene blue) in a sinus/fistula to delineate the cavity/tract respectievely as in a pilonidal sinus [Figure 5], presternal sinus. The hypodermic needle needs to be removed to avoid false tract formation.

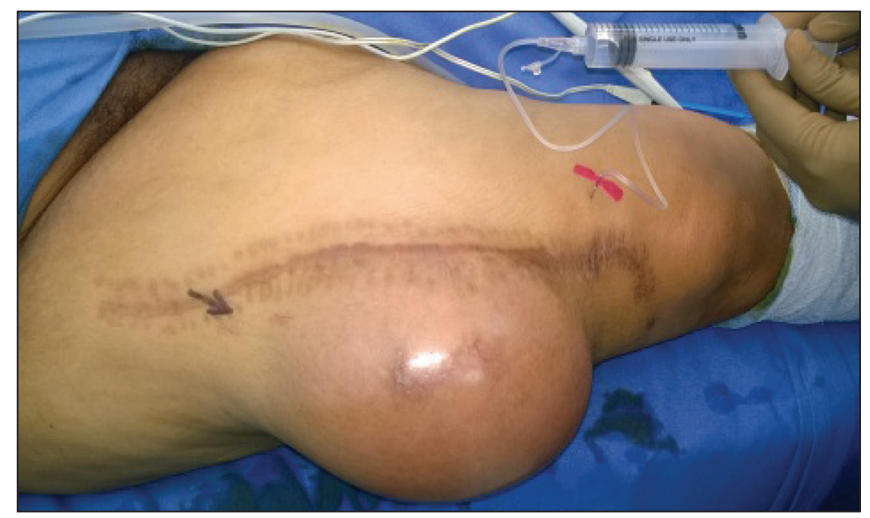

Figure 1: Tissue expander inflation

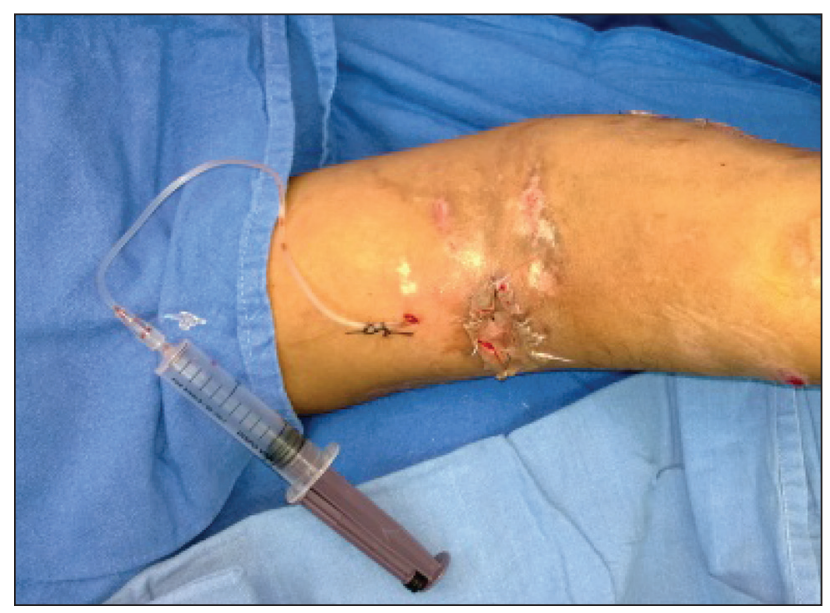

Figure 2: Continuous suction drain with $10 \mathrm{cc}$ syringe and piston of $2 \mathrm{cc}$ syringe

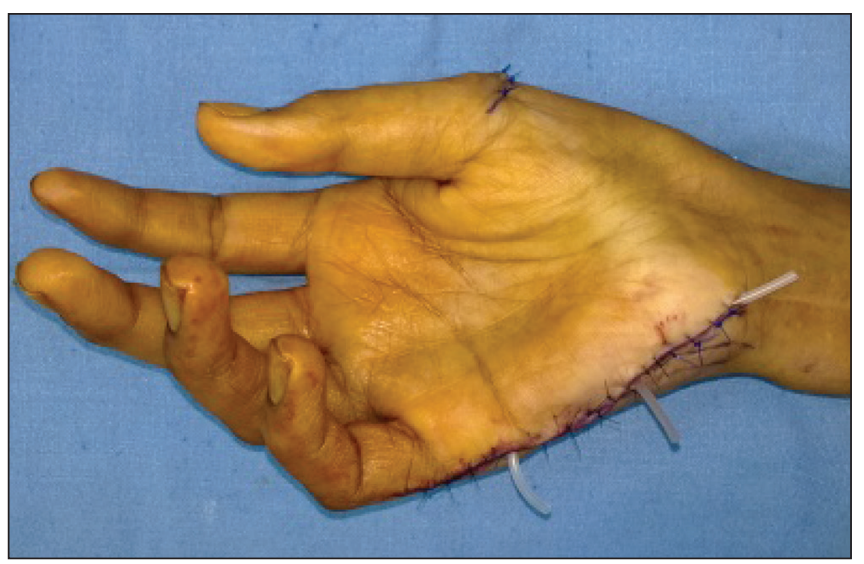

Figure 3: Penrose type tube drains post-Huber transfer of ADM(Abductor Digiti Minimi) for thumb Opposition

Scalp vein set can be used to cover the cut sharp end of K-wires during fracture fixation of digits [Figure 6].

Apart from this, it is used for venipuncture, which is its primary function not limited to any particular specialty. Scalp vein set is a very cheap and easily available device which can be used in various procedures. It can be used as a replacement for Romo Vac Set (Romsons Scientific 


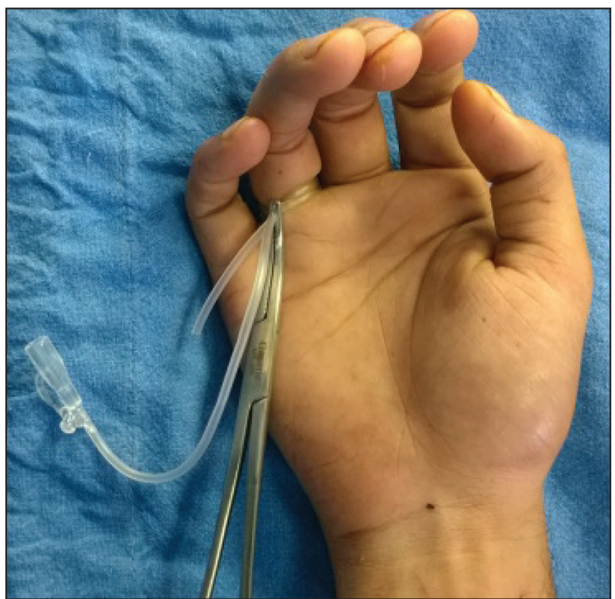

Figure 4: Finger tourniquet

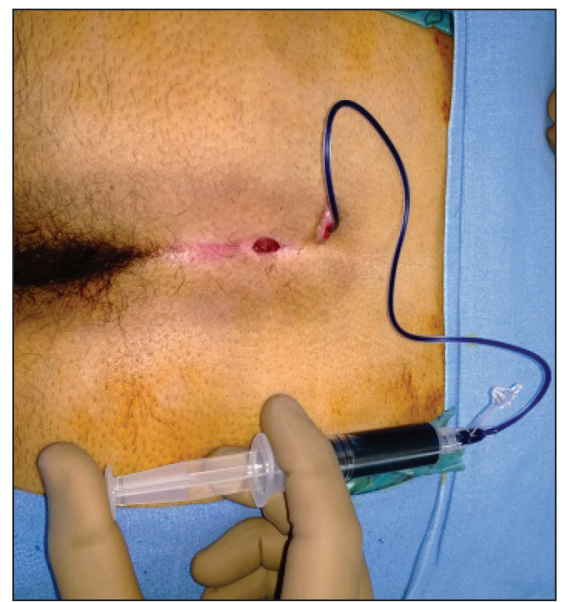

Figure 5: For instillation of dye in pilonidal sinus

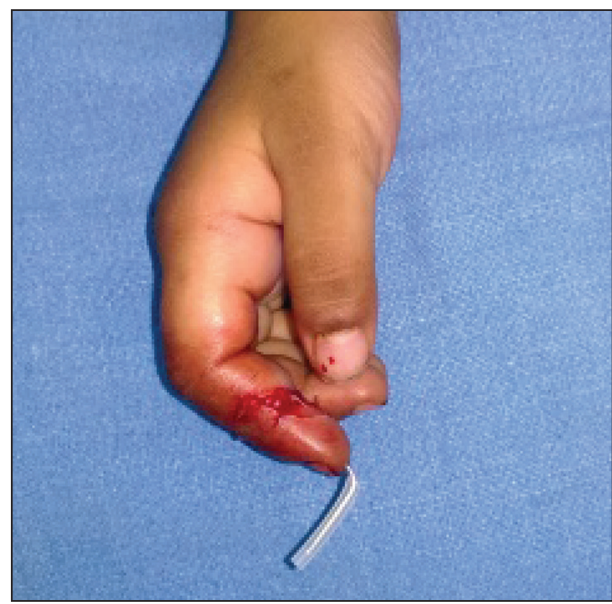

Figure 6: For covering sharp end of K-wire

and Surgical Industries, Nunhai, Agra, India) for drainage, for infant feeding tube and glove as finger tourniquet and for venflon as for intravenous access.

\section{Financial support and sponsorship}

\section{Nil.}

\section{Conflicts of interest}

There are no conflicts of interest.

\section{Hardeep Singh, Rakesh Kumar Khazanchi, Aditya Aggarwal, Sanjay Mahendru, Vimalendu Brajesh, Sukhdeep Singh}

Department of Plastic, Reconstructive and Aesthetic Surgery, Medanta - The Medicity, sector 38 Gurgaon, NCR,

Haryana, India

Address for correspondence: Dr. Hardeep Singh, Department of Plastic Reconstructive and Aesthetic Surgery, Medanta - The Medicity, Sector 38, Gurgaon - 122 001, NCR, Haryana, India. E-mail: drhardeepaulakh@gmail.com

\section{REFERENCES}

1. Neviaser RJ. Infections. In: Green DP, editor. Operative Hand Surgery. $3^{\text {rd }}$ ed., Vol. 1. New York: Churchill Livingstone; 1993. p. 1021-33.

2. Turan A, Kul Z, Ozygit T, Gözü A, Ozsoy Z. Use of the scalp vein infusion set for irrigation in infections of the hand. Plast Reconstr Surg 2004;114:1004-5

This is an open access article distributed under the terms of the Creative Commons Attribution-NonCommercial-ShareAlike 3.0 License, which allows others to remix, tweak, and build upon the work non-commercially, as long as the author is credited and the new creations are licensed under the identical terms.

\begin{tabular}{|l|l|}
\hline \multicolumn{2}{|c|}{ Access this article online } \\
\hline Quick Response Code: & Website: \\
\hline & www.ijps.org \\
\cline { 2 - 2 } & \\
\hline
\end{tabular}

How to cite this article: Singh $\mathrm{H}$, Khazanchi RK, Aggarwal A, Mahendru S, Brajesh V, Singh S. Extended uses of scalp vein set in plastic surgery. Indian J Plast Surg 2015;48:222-3. 